\title{
Comments
}

\section{CONSTITUTIONALITY OF SECTION 610 OF THE FEDERAL CORRUPT PRACTICES ACT}

Section 610 of the Federal Corrupt Practices Act makes it a crime for a corporation or a labor union to make a "... contribution or expenditure in connection with ..." federal elections. ${ }^{1}$ As the Supreme Court has pointed out, ${ }^{2}$ the aim of the mitial legislation forbidding political activity was to preserve the integrity of the electoral process and keep the voter alert to his responsibilities. The 1947 amendments show additional objectives. One was to keep labor unions out of politics ". . . in the same way that corporations are supposed to keep out of politics."3 The dominant theme, however, was a desire to protect the dissenting minority who must belong to a union to earn a living and who are thus forced to contribute through general union dues to espouse a candidate whose views they do not favor. ${ }^{4}$ This comment will explore the difficult imterpretative and constitutional problems raised by section 610 and will discuss the advisability of the section in its current form.

\section{SCOPE OF THE STATUTE}

At the outset it should be noted that the statute does not apply to state elections, to activities by persons acting as individuals, or to lobbying and similar attempts to influence legislation other than through the use of organized power in elections. There are questions, however, which cannot be answered from a reading of the statute alone: (1) Most important, what activity is included within the term "expenditures"?5 (2) What does the phrase "in connection with" mean? (3) Is there an intent element involved? (4) Does the section apply not only to busmess corporations but also to political groups which happen to have a corporate structure? ${ }^{6}$

Appellate courts have been called upon to define the scope of the term "expenditures" in three cases. In United States v. CIO,7 the Supreme Court held that the distribution of the CIO News, supported by union dues, to dues-paying members and to those of the general public who purchased the News was not an expenditure within the terms of the statute. ${ }^{8}$ Althougl the Senate debate indicates otherwise, ${ }^{8}$

118 U.S.C. $\$ 610$ (1952). The progenitor of section 610 was 34 STAT. 864 (1907), applying to corporations and money contributions. The most recent extensions are: to labor unions, 57 STAT. 167 (1943) made permanent by the present act, 61 STAT. 159 (1947); to expenditures in addition to contributions, and to primaries, conventions and caucuses in addition to elections. See note 19 infra. For a conplete history of section 610, see United States v. International Union United Automobile Workers, CIO, 352 U.S. 567 (1957); Kallenbach, The Taft-Hartley Act and Union Political Contributions and Expenditures, 33 MTNN. I. Rev. 1 (1948).

2 United States v. International Union United Automobile Workers, CIO, 352 U.S. 567, 575 (1957).

393 Cong. Rec. 6440 (1947).

4 Id. at 6437-40, 6447-48; see Curtis, Regulation of Union Political Expenditures, Am. Econ. Sec., May-June, 1956, p. 16.

518 U.S.C. $\$ 591$ (1952) defines "expenditures" and "contributions" in practically the same broadly inclusive terms.

6 The statute refers to any corporation whatever while labor unions are defined as organizations whose purpose is to deal with employers. 18 U.S.C. $\$ 610$ (1952).

7335 U.S. 106 (1948).

8 The district court had granted defendant's motion to dismiss on the ground that the act was unconstitutional. United States v. CIO, 77 F. Supp. 355 (D.D.C. 1948). The Supreme Court affirmed the dismissal on the statutory construction ground and did not consider the constitutional question.

993 Cong. Rec. 6437 (1947). 
the Court reasoned that house organs were not within the prohibited area as long as distribution was only among organization members, and that to the extent copies were sold to the general public, the News became a self supporting newspaper similar to a commercial newspaper and thus was exempt from the operation of the statute. The United States Court of Appeals for the Second Circuit, in United States $v$. Painters Local $481,{ }^{10}$ extended this reasoning to exempt a radio broadcast beamed to the general public. Eight years later, in United States v. International Union United Automobile Workers, CIO, ${ }^{11}$ the Supreme Court, on appeal from an order dismissing an indictment which charged that a television broadcast beamed to the public at large was paid for from general union dues, ignored the Painters Local case and held that the facts alleged would be an expenditure under section 610 , reasoning that "the evil at which Congress has struck $\ldots$ is the use of corporate or union funds to influence the public at large . . . "12 The Court refused to consider any of the constitutional questions on the indictment alone and remanded for a trial on the merits, pointing out that the following questions of fact might be relevant in determining if there had been an illegal expenditure: ${ }^{13}$ (1) whether the expenditure was from general dues or froin volun tary contributions of the members; (2) whether the broadcast reached the public at large or only union members; (3) whether the expenditure involved active electioneering or only the publication of statistics or records of candidates; ${ }^{14}$ and (4) whether or not the expenditure was made with intent to affect the results of the election. ${ }^{15}$ Only the first two of these questions of fact have actually been lield to be determinative, but it also seems reasonable to rely on the other two.

The remaining constructional problems may be dealt with summarily. The Senate debates indicate that the courts are to have much discretion by stating that the scope of the phrase "in connection with" is to be determined by how closely the expenditure was tied in with something which was a direct issue in the election. ${ }^{16}$ The Senate debate and dicta by the Court in $U A W$ indicate that there may be a requirement that the organization use its funds with intent to influence an election. ${ }^{17}$ Finally, despite the fact that neither Congress nor the Court has spe-

10172 F.2d 854 (2d Cir. 1949).

11352 U.S. 567 (1957).

12 Id. at 589. The Court distinguished the CIO case as involving purchasers whereas the indictment in $U A W$ alleged that the television programs reached the general public gratis.

13352 U.S. at 592. The Court also voiced the opinion that, by remanding, the case might be disposed of on the merits. At the subsequent trial, the jury returned a verdict of not guilty. N.Y.Times, November 7, 1957, p. 1, col. 4 .

14 This distinction originated in the Senate debate. 93 Cong. REc. 6447 (1947). The dissent, 352 U.S. at 598 , asks why the constitutional guarantee should be given only to the ". . . meaningless mouthings of ineffective speakers." Perhaps the basis for this otherwise unexplainable exception is that this would be education in the proper sphere of the self interests of an organized group as opposed to propaganda against which a gullible public has no defense.

$15 \mathrm{Mr}$. Justice Frankfurter, writing for the majority, said that these factual distinctions were not intended as answers for statutory construction problems, 352 U.S. at 592 , but what else could they be?

1693 Conc. Rec. 6447 (1947). This of course helps but hitle. We are still left with factual questions as to the effect of time, distance and content of the publication.

17 Id. at 6439. See United States v. International Union United Automobile Workers, CIO, 352 U.S. 567, 587 (1957) for borderline situations which involve perplexing questions of intent. 
cifically discussed whether political organizations with corporate structures are included within section 610 , the language seems conclusive when it refers to "... any corporation whatever ...." However, if the case should ever arise, such corporations might escape the operation of the section on the theory that their funds are all derived from voluntary contributors who expected the money to be used for political purposes.

The explanations of the congressional debate as augmented by judicial interpretations ${ }^{18}$ permit paraphrasing section 610 in this manner: It is unlawful for any corporation whatever, or any labor organization, to make a contribution or expenditure of general organization funds (as distinguished from the voluntary contributions of members or stockholders) with intent to influence the public at large (as distinguished from organization members and purchasers of organization newspapers) by active electioneering (as distinguished from a bare statement of statistics or records of candidates) in connection with federal elections, prinaries, conventions and caucuses.

\section{CONSTITUTIONAIITY OF THE STATUTE}

The power of Congress to enact corrupt practices legislation derives from its power to regulate the times, places and manner of holding elections. ${ }^{10}$

The most troublesome constitutional issue is whether the prohibition of expenditures is an unconstitutional deprivation of the right of free speech, as corporations or labor unions must make expenditures of some kind in order to speak as a group. Since this presents the first sharp focus between group as opposed to individual freedom of speech, ${ }^{20}$ no attempt will be made to rationalize in full the welter of cases dealing with the free speech of individuals. ${ }^{21}$ Instead the most recent verbalizations of the "clear and present danger" doctrine ${ }^{22}$ will be used to test the constitutionality of section 610 in connection with both the integrity in elections rationale and the minority rights rationale for the statute. The test as accepted in Dennis v. United States" is " "whether the gravity of the 'evil' discounted by its improbability, justifies such invasion of free speech as is necessary to avoid the danger.'"

18 Other than the CIO, UAW and Painters Local cases discussed in the text, there are only two reported cases interpreting section 610: United States v. Construction and General Laborer's Union, 101 F. Supp. 869 (W.D.Mo. 1951) and United States V. United States Brewers' Ass'n, 239 Fed. 163 (W.D.Pa. 1916).

19 U.S. Const. art. I, § 4; Burroughs v. United States, 290 U.S. 534 (1934). While there may have been doubt in the past, United States v. Classic, 313 U.S. 299 (1941), n1ay be regarded as warranting extension of the act to primaries, conventions and caucuses.

20 In most instances the rights of the organization have been vindicated through the rights of the individual. See Thomas v. Collins, 323 U.S. 516 (1945); Hague v. CIO, 307 U.S. 496 (1939). Cf. Joint Anti-Fascist Refugee Committee v. McGrath, 341 U.S. 123 (1951). As shown above (see Scope of the Statute, supra) the statute does not apply to individuals unless they are making use of a group expenditure. The picketing cases show some proclivity not to be overly solicitous of umion first amendment claims but they are not in point because speech is only a small part of the total pressure exerted. See Teamsters Union, AFL v. Vogt, 354 U.S. 284 (1957). United Public Workers, CIO v. Mitchell, 330 U.S. 75 (1947) is not in point because in that case the statute regulated only the internal machinery of the government itself.

21 For a full discussion, see Mendelson, Clear and Present Danger-From Schenck to Dennis, 52 Coluar. L. Rev. 313 (1952).

22 See Schenck v. Umited States, 249 U.S. 47 (1919).

23341 U.S. 494, 510 (1951) (opimion of Chief Justice Vimson). It seems appropriate to use the Dennis test here because of the analogy between the political anarchy statute in Dennis and the instant political corruption statute. Both fit under the broad category of protecting the basic American democratic processes. Compare Yates v. United States, 355 U.S. 66 (1957). 
How grave is the evil? If elected representatives owed their allegiance to concentrations of money rather than to the people, the electorate would not be properly represented and thus would lose faith in the government, and anarchy or authoritarianism would ultimately result. Hypothetically, a total subversion of the electoral process through political corruption constitutes a very grave evil.

A number of conflicting factors make it much more difficult to condemn abrogation of minority political rights as a grave evil. Because of the size of the voting population in the United States, the individual voice does not often make a deep impression; it is only through concerted action that political views may be effectively expressed. This, among other considerations, leads to one of the basic tenets of a democratic system: the minority must abide by the will of the majority. ${ }^{24}$ But a fundamental premise for this tenet is that membership in the organization is voluntary; yet under the Taft-Hartley Act, ${ }^{25}$ in nore instances than can be ignored, the individual joins a union not voluntarily but under economic compulsion. Of course many individuals other than wage earners are under compelling economic pressures of varying degrees to join organizations with political overtones. ${ }^{26}$ Nevertheless, in the writer's opinion, two factors justify making involuntary participation in union political activity an evil against which the individual should be protected: (1) the direct and immediate pressure of the choice between working and not working in his trained skill and (2) the fact that the federal government has sanctioned the pressure.

The minority rights consideration seems to lose force when attention is turned to stockholders of a corporation simce their membership is essentially voluntary ${ }^{27}$ and since they have a more direct remedy through a stockholder's suit to enjoin ultra vires actions. However, section 610 may be considered as an auxiliary method of protecting minority stockholders against political contributions or expenditures outside the corporate purpose. ${ }^{28}$

Is the evil so probable that legislation is necessary? It seems fairly certain that the use of union and corporate funds for political purposes would result in derogation of minority rights and that direct or indirect contributions or expenditures by corporations or labor unions would have some effect on integrity in elections.

24 Cf. J. I. Case Co. v. NLRB, 321 U.S. 332, 339 (1944) (“. . . individual advantages or favors will generally in practice go in as a contribution to the collective result.").

2561 STAT. 140, 142 (1947), 29 U.S.C. $\$ \$ 158(a)(3), 159$ (e) (1952).

26 Consider the economic pressure on a merchant to join the local chamber of commerce, or an independent contractor to join lis trade association, or on a school teacher to join her state teachers' association. Senator 'Taft said that if abuses arose with respect to other unincorporated associations, the act could be extended. 93 Covg. Rec. 6440-41 (1947). In any event, should protection be denied to members of one group because it is denied to members of another?

27 See text following note 17 supra discussing the applicability of section 610 to corporations with a political purpose.

28 Donations to political organizations are generally held to be ultra vires. BAIIANTINE, Corporations $\$ 85$ (rev. ed. 1946); cf. Morgan v. Tate \& Lyle, [1954] 2 All E.R. 413 (H.L.) where an expenditure against a proposal to nationalize imdustry was held to be a tax deductible expense. The argument has been made that the constitutions of labor unions differ vastly in intent and purpose from corporate charters and that labor unions traditionally give advice and information concerning political issues and candidates. Hearings before Special Howse Committee to Investigate Campaign Expenditures for 1952, 82d Cong., 2d Sess. at 219 (1952). But what difference can this make? Corporations are voluntary, but if not formed for political purposes, should not engage in them. Labor unions are formed partially for political purposes but are not voluntary in the same respect as are corporations. 
Since the question of probability ${ }^{29}$ lies largely in the realm of conjecture, congressional determination that legislation is necessary should be conclusive unless otherwise unreasonable. ${ }^{30}$

May the restraints on group speech be justified? A statute completely prohibiting free speech by certain groups ${ }^{31}$ should be narrowly drawn to ineet the specific evil; ${ }^{32}$ the abuses should be curtailed, not the rights theinselves. ${ }^{33}$ If the abuse sought to be corrected is corruption, then the statute should be aimed at atteinpts to influence elections which are intended to corrupt the candidate or at activities which actually have led to corrupting combinations. The assumption that every attempt to influence an election through group action necessarily leads to corruption is not justified; it presupposes a coinplete lack of requisite moral integrity in every elected representative, ${ }^{34}$ as well as in those exerting group influence. If section 610 were a complete prohibition of group speech, it would be unconstitutional because it would be too broadly drawn, striking down non-corrupting as well as corrupting speech.

But on closer inspection it is found that the act does not completely prohibit group speech of a political nature. The existing group structure may be utilized for political purposes by providing for earmarked voluntary contributions by members within that structure ${ }^{35}$ or by erecting parallel organizations which interested nembers nay either reject or join and support. ${ }^{36}$ When the abridgment is not complete but limited or regulatory the Court has balanced the effects of the statute on free speech with the congressional determmation of necessity. ${ }^{37}$ Section 610 , as liberally interpreted, imposes only partial restrictions. It also resolves two conflicting aims: expenditures of non-voluntary funds, some of which are being used against the political beliefs of their donors, are stopped while at the same time the organizational value of the union is still realized for political purposes. But counterbalancing these salutary effects of the section are the practical problems which the unions encounter. It takes time and effort to erect parallel structures. There may be embarrassing lack of funds due to apathy among the members. The union unay not be able to speak as representative of the full weight of the union. In balancing these considerations, it seems that as to labor unions, the evil is eliminated while the right of free group speech is left intact with but few limitations on its effective use.

29 The question of probability was not so crucial in Dennis, where the defendant was convicted of intentionally advocating overthrow, as it is under section 610 when defendant is convicted of intent to influence elections which may or may not involve corruption.

30 American Communications Ass'n, CIO v. Douds, 339 U.S. 382 (1950).

31 An organization has the right to free speech. U.S. Const. amend. I is not couched in terms of the individual; rather it provides that "Congress shall make no law ... abridging freedoin of speech ...." Cf. U.S. CoNsT. amend. XIV (protection is given to "citizens" and "persons"). See Bowe v. Secretary of the Commonwealth, 320 Mass. 230, 69 N.E.2d 115 (1946) where the court held invalid a proposed initiative measure similar to section 610 primarily on the importance of effective group speech.

32 Cantwell v. Connecticut, 310 U.S. 296, 311 (1940).

33 De Jonge v. Oregon, 299 U.S. 353, 364-65 (1937).

34 Cf. Newman, Money and Elections Law in Britain-Guide for America?, 10 THE WeSTERN POLITICAL QUARTERLY 582, 602 (1957), concluding that America cannot yet match the firm traditions of honesty and integrity in politics that Britons have.

35 See text following note 13 supra for dicta of the Court that pohitical expenditures from voluntary contributions are not prohibited.

36 As an organization purely for political purposes and not for union-management relations purposes, a group such as the Committee of Political Education (COPE, AFL-CIO) does not fit within the statutory definition of "labor organization." 18 U.S.C. \$ 610 (1952). See note 6 supra.

37 American Communications Ass'n, CIO v. Douds, 339 U.S. 382 (1950). 
It is difficult to imagine the organization of a parallel structure for political purposes by corporation stockholders. But that does not mean that the section is unconstitutional as to corporations ${ }^{38}$ because it is a complete prohibition rather than a limited infringement. The section may be considered only a limited infringement on corporate political activities because the existing corporate structure may be used as a basis for voluntary political activity and because the corporation may inform its stockholders of the political activity of candidates under the reasoning of the $C I O$ case. ${ }^{39}$ The fact that management, because of its personal wealth, may espouse its group political views through devices not available to the relatively less affluent union ineinbers, ${ }^{40}$ while not directly affecting the constitutionality of the section, tends to make the case for the corporation less strong. The prohibition against corporate expenditures, though complete on its face, is in fact only a limited abridgment.

It seems that section 610 meets the Dennis test and that, both as to corporations and labor unions, the limited restrictions may be justified when balanced against the evils of corruption and abrogation of minority political rights. Section 610 is a potent tool for protecting the objecting individual from the use of his money for political purposes. It also tends to reduce corruption, but only at the cost of limiting non-corrupting as well as corrupting speech. However, since the integrity of elections and minority rights may be protected without excessive hobbles on group action, the section, as interpreted, is constitutional. ${ }^{41}$

\section{ADVISABIIITY OF THE STATUTE}

Although proposals to change the existing law might have been expected as a reaction to labor union and corporation excesses in pohtics, ${ }^{42}$ the Subcommittee on Privileges and Elections of the Senate Committee on Rules and Administration (The McClellan Committee) las recommended that section 610 be reenacted verbatim in the proposed "Political Activities Disclosure Act." 43 Nevertheless, advocacy of change in the statutory proscription is not lacking. ${ }^{44}$

The unions argue with force that one of the objectives of section 610 , to put labor on a similar political footing with corporations, is misconceived; that the

38 The only reported case on corporations held the section to be constitutional as it existed in I916. United States v. United States Brewers' Ass'n, 239 Fed. 163 (W.D. Pa. 19I6).

${ }^{39}$ In the $C I O$ case, the Court reasoned that house organs were not within the prohibited area as long as distribution was only among organization members. See text following note 9 supra.

40 The $\$ 5,000$ personal limitation, 18 U.S.C. $\$ 608$ (1952), may be utilized by each member of a wealthy fanily or may be expended many times to each of several pohtical committees. Mitau, Selected Aspects of Centralized and Decentralized Control over Campaign Finance: $A$ Commentary on S. 636, 23 U. CHI. L. REv. 620, 624-26 (1956); Norton-Taylor, How to Give Money to Politicians, Fortune, May, 1956, p. 113. It might be supposed that some corporate executives are "expected" to contribute to political campaigns.

41 Contra, Comment, 57 Yade L.J. 806 (1948).

${ }^{42}$ See S. Rep. No. 395, 85th Cong., 1st Sess. 9-33 (Corporations), 115-18 (Labor) (1957).

43 Id. at 152 .

44 Codifying some distinction between voluntary and non-voluntary groups by making the prohibition apphicable to business corporations or non-political corporations instead of any corporation whatever would serve to allay the fear that section 610 opens the door to vast prohibitions on all pressure groups such as the Chamber of Commerce or the American Legion. Cf. Laws of Wisc. 1955, c. 135, State v. Joe Must Go Club of Wisconsin, Inc., 270 Misc. 108, 70 N.W.2d 681 (1955); Minn. StaT. \$210.20 (1957); Mich. Acts 1954, No. 116, § 168.919; PA. STat. ANN. tit. 25, $\$ 3225$ (b) (1954). For a survey of state corrupt practices legislation see Brown, State Regulation of Union Political Action, 6 LAB. L.J. 769 (1955). 
prohibition against expenditures has greater practical impact on unions than on corporations because of the fundamentally different economic positions held by each. The unions say, for example, that management can get free espousal of its political views by putting economic pressure on newspapers in which they advertise while unions actually have to make expenditures to present their side of the picture. ${ }^{45}$ They also argue that management through its personal affluence can accomplish what labor must organize to do. ${ }^{46}$

One method of preserving the organizational value of unions while still protecting minority rights of the members would be to provide that union members would have to "contract in" to become liable for a political assessment or to "contract out," as in Britain, ${ }^{47}$ in order to avoid such an assessment. The contracting in system should tend to eliminate to a degree the "goon squad" pressure put on a member who attempted to contract out; the contracting out system puts apathy on the side of increased political activity by requiring a member to act positively in order to escape assessment. It would seem that the voluntary parallel structure system whicl the Court has sanctioned is similar to the contracting in system. ${ }^{48}$ While legislation thus might not seem necessary, there are arguments that a contracting out system would be a better solution. If pressure could be kept off the individual member by enabling him to contract out by filing with an impartial agency such as the National Labor Relations Board, the enactment of a contractmg out provision would not only tend to eliminate embarrassing lack of political funds but would also tend to eliminate cries of foul play when unions do use voluntary funds. ${ }^{40}$

A complaint has been raised as to the prosecutor's discretion problem involved in a vague statute..$^{50}$ Because of the peculiar operation of corrupt practices legislation, Congress cannot expect the Department of Justice to enforce section 610 effectively unless its applicability to a given fact situation is precisely spelled out. The obvious political overtones of the section coupled with its literal uncertainty would tend to result in a decision not to prosecute unless the section clearly applied. Further, the vigorous prosecution that miglit be expected despite vagueness in a criminal narcotics statute, for example, cannot be expected when the defendants are likely to be pillars of the community. For these reasons a definitive body of case law has been slow im coming.

The prohibition against any "expenditure," being so all inclusive, is at the heart of the vagueness problem. While the prohibition against direct contributions slould be retained, a solution might be to restrict the broad prohibition against all indirect expenditures (not necessarily money only) to those situations where there exists a conspiratorial relation or a relation where the candidate might feel overly obligated. ${ }^{51}$ Other than this, it is submitted that the $U A W$ and $C I O$ cases, by hiting the broad sweep of the word "expenditures" with regard to labor unions, render

45 Sutherland, The Constitutionality of the Taft-Hartley Law, 1 IND. \& LAB. Rex. 176, 183-84 (1948).

46 See note 40 supra.

47 Trade Disputes \& Trade Unions Act, 1946, 9 \& 10 GEo. 6, c.52. See also Newman, Money and Electionu Law in Britain-Guide for America?, 10 The Western PolITICAT QUARTERLY 582, 592-93, n.24 (1957).

48 See text following notes 13 and 35 supra.

40 E.g., Hunan Events, Noveniber 30, 1957, Article Section.

50 Hearings before the Subcommittee on Privileges and Elections of the Senate Committee on Rules and Admiuistration, 84th Cong., 1st Sess. at 209-10 (1955).

51 Cf. Laws of Wisc. 1955, c. 135; IND. ANN. Stat. \$29-5712 (1949); La. Rev. Stat. $\S 18: 1483$ (1950). 
The most serious charge is that section 610, like most of the Corrupt Practices Act, is madequate. ${ }^{52}$ The remedy is not in more prohibitory legislation since in that direction lies the danger of unconstitutionality. Suggestions have been made that the section is impossible to enforce or improve and should be repealed, ${ }^{53}$ or that complete or partial government subsidy of campaign expenses is the best answer. ${ }^{.54}$ Perhaps the practical way to deal with the problem is not by prohibition which merely tends to drive abuses underground but by free and prompt publicity so that an intelligent public will know from whence comes the advocacy. ${ }^{65}$ This is one of the aims of the McClellan Committee's proposed "Political Activities Disclosure Act."

\section{CONCLUSION}

Section 610 brings to light a basic philosophical dichotomy between some members of the Supreme Court and the Congress. Congress assumes that the public will be adversely affected by an unbalanced spending of money in a campaign and that public elective officials will be corrupted by any independent espousal by corporations or labor unions. ${ }^{56}$ On the other hand, the dissent in $U A W^{57}$ exemplifies the theory that the pubhic will be educated rather than adversely infiuenced, that partisan expenditures help make elections an adversary proceeding where the best platforms and candidates will einerge triumphant.

The constitutionality of section 610 depends on liberal interpretation. Some comparatively minor features such as the right to erect parallel structures might possibly be elimmated, but if completely voluntary political activity is curtailed, the section would be unconstitutional. Thus it seems that prohibitory legislation has almost reached its outer perimeter and that care must be taken unless constitutional grounds are to be transgressed. This is not to say that the section is satisfactory. Changes need to be made. Minority protection might better be ensured by enactimg provisions for contracting in or out of political assessinents. More important, prospective legislation should narrow the broad prohibition against all expenditures and mstead prohibit indirect contributions only where the element of conspiracy is present. ${ }^{58}$ The desire to make section 610 effective should not overwhelm our basic interest in group free speech.

Wilbur D. Layman

52 Mitau, Selected Aspects of Centralized and Decentralized Control over Campaign Finance: A Commentary on S.636, 23 U. CH. L. REv. 620 (1956). The most recent complaints involve the use of union manpower at the polls reimbursed from general union dues. See the separate views of Senator Goldwater in S. REP. No. 395, 85th Cong., 1st Sess. 159 (1957). Senator Goldwater has proposed to deny the union shop to umions which are active politically. Washington Post, Feb. 3, 1957, p. A10, col. 3.

53 S. REP. No. 395, 85th Cong., 1st Sess. 138 (1957).

54 Senator Neuberger is the most ardent advocate of this position. See id. at 114; 103 CoNo. REc. 11894 (daily ed. July 31, 1957).

55 Kallenbach, The Taft-Hartley Act and Union Political Contributions and Expenditures, 33 MinN. L. Rev. 1 (1948).

50 As already discussed, the purpose of the initial legislation in 1907 was to preserve the integrity of the electoral process while that of the 1947 amendments was to put labor on the same political footing with corporations (as well as to protect minority rights). It may well be that Congress no longer assumes easy corruption of public elective officials but is afraid to advocate dropping restraints on either corporations or unions because of the possible political repercussions in the home districts and thus prefers the present approxinate balance of power. 57 United States v. International Union United Automobile Workers, CIO, 352 U.S. 567, 593 (1957) (dissenting opinion).

68 See text at note 51 supra. 